www.jmscr.igmpublication.org

Impact Factor (SJIF): 6.379

Index Copernicus Value: 79.54

ISSN (e)-2347-176x ISSN (p) 2455-0450

crossrefDOI: https://dx.doi.org/10.18535/jmscr/v6i11.54

\title{
Marrow Iron Status and its Correlation with Serum Ferritin in Anaemia of Chronic Kidney Disease
}

\author{
Authors \\ Arun T Korah ${ }^{1}$, Aruna $\mathbf{R}^{1^{*}}$ \\ ${ }^{1}$ Department of Internal Medicine, Government Medical College, Thiruvananthapuram, Kerala, India \\ *Corresponding Author \\ Dr Aruna R
}

Additional Professor, Department of Internal Medicine, Government Medical College, Thiruvananthapuram, Kerala, India

Phone No.: +91 9447753729, Email: arunavraman@gmail.com

\begin{abstract}
Anemia, a common entity in Chronic Kidney Disease can increase the morbidity and mortality. This study was done to determine the haematological profile and bone marrow stores in patients with anemia of CKD and also to study the usefulness of serum ferritin as a single screening tool for assessing the status of body iron stores. 35 patients with chronic Kidney disease and a hemoglobin level less than $10 \mathrm{~g} / \mathrm{dl}$ were assessed in this study. Their sociodemographic details and aetiology of the disease was noted. Reports of Hemogram, Peripheral smear and other investigations like Blood urea, Serum creatinine, Serum calcium, Uric acid, Serum albumin, Serum Ferritin etc were also noted. Glomerular filtration rate was estimated using the Cockcroft Gault Formula. Bone marrow aspiration was done and the aspirate was semi quantitatively graded for its iron content. Data collected was entered in Microsoft excel 2010 and analysed. It was found that $60 \%$ were males and common causes were diabetes mellitus and hypertension. $45.7 \%$ had hypochromic microcytic anemia. Mean creatinine and blood urea were $9.8 \mathrm{mg} / \mathrm{dl}$ and $163 \mathrm{mg} / \mathrm{dl}$ respectively. A Normocellular marrow was seen in majority of cases. A significant correlation was seen between serum ferritin level and bone marrow iron status. It was concluded that serum ferritin estimation can be used as a screening test to detect the iron status in patients with anemia of Chronic Kidney Disease

Keywords: Anemia, Chronic kidney Disease, Serum Ferritin, Haemoglobin, Bone marrow iron stores.
\end{abstract}

\section{Introduction}

Chronic Kidney Disease, a common problem in India affecting 35 lakh people ${ }^{1}$, is often associated with anemia, which causes increased morbidity and mortality. In the Indian population, iron deficiency in anemia of Chronic Kidney Disease is seen in $50-60 \% \%^{2,3}$. This study was done to determine the haematological profile and bone marrow stores in patients with anemia of CKD and also to study the usefulness of serum ferritin as a single screening tool for assessing the status of body iron stores.

\section{Methods}

This cross sectional descriptive study was done on 35 chronic Kidney Disease (CKD) patients with 
serum creatinine level more than $3 \mathrm{mg} / \mathrm{dl}$ and a haemoglobin level less than $10 \mathrm{~g} / \mathrm{dl}$ who had documented serum creatinine of $>2 \mathrm{mg} \%$ or bilateral contracted kidney at least one month prior to the study, who never underwent haemodialysis, blood transfusion, Intravenous Iron therapy or erythropoietin therapy and no evidence of Acute kidney injury.

The sociodemographic details of the patients and aetiology of chronic renal failure were recorded in a predesigned proforma. Hemogram was done using an automated analyser and the following parameters were noted:

- Haemoglobin ( $\mathrm{Hb}$ ), Haematocrit or Packed cell volume (PCV), WBC count, Platelet count.

- Mean red cell volume(MCV): (Haematocrit x 10 / Red cell count x 106)

- Mean red cell haemoglobin (MCH): (Haemoglobin x 10 / Red cell count x 106)

- Mean cell Hemoglobin concentration (MCHC): (Hemoglobin $\mathrm{x} \quad 10$ / Haematocrit)

- Red cell distribution width (RDW), Reticulocyte count.

- Reticulocyte Production Index (RPI): (Reticulocyte count $x$ haemoglobin correction / Maturation time correction).

- Hemoglobin correction: (Actual $\mathrm{Hb} /$ Expected $\mathrm{Hb}$ ).

If haematocrit is around $25 \%$, maturation correction factor is taken as 2 and if haematocrit is 15 , then latter is taken as 2.5 .

Peripheral smears of patients were taken and examined after Giemsa staining. The RBCs were examined and the anemia categorized into normochromic-normocytic, hypochromicmicrocytic and macrocytic. The WBCs were examined for any abnormalities including toxic granules, shift to left and differential counts were confirmed.

Reports of biochemical investigations like Blood urea, Serum creatinine, Serum calcium, Uric acid, Serum albumin, Serum Ferritin were also noted. Glomerular filtration rate was estimated using the
Cockcroft Gault Formula77ie GFR = (142-Age)

X Weight $(\mathrm{kg})$

72-Creatinine

Bone marrow aspiration was done and the aspirate was subjected to iron staining. The smear was semi quantitatively graded using Prussian blue reaction for its iron content.

\section{Results}

Out of the 35 patients enrolled in this study, $60 \%$ were males and $40 \%$ were females. Figure 1 shows the age wise distribution of patients. Mean age was 57 years. Maximum number of cases were within the 50 to 60 year age group (Figure 1).

Figure 1: Age wise distribution of patients

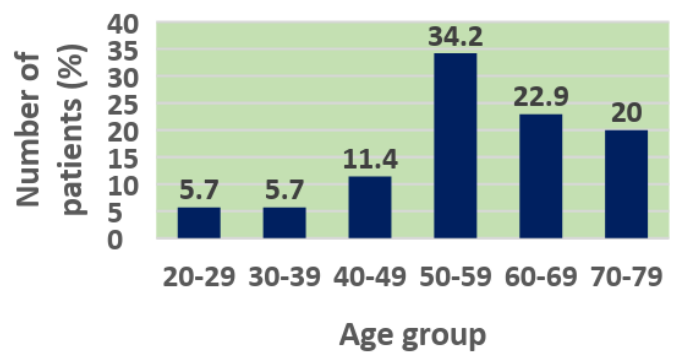

Figure 2 shows the aetiology of CKD in the study population. $60 \%$ patients developed CKD due to diabetic nephropathy and in $20 \%$, it was due to hypertension.

Figure 2: Aetiology of CKD in study population

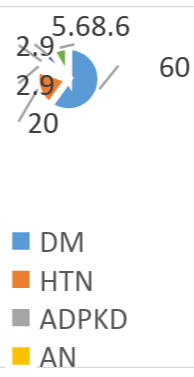

(DM: Diabetes Mellitus, HTN: Hypertension, ADPKD: Cystic kidney disease, AN: Analgesic nephropathy, CGN: Chronic glomerulonephritis (CGN), I: Idiopathic)

$\mathrm{Hb}$ levels of the patients ranged from $3.69 \mathrm{gm} / \mathrm{dl}$ to $9.2 \mathrm{gm} / \mathrm{dl}$. The mean $\mathrm{Hb}$ was $6.9 \mathrm{gm} / \mathrm{dl} .3$ patients had $\mathrm{Hb}$ less than $5 \mathrm{gm}$, /dl. Mean values for PCV, MCV, MCH and MCHC were 22\%, 83 $\mathrm{fl}, 25.8 \mathrm{pg} /$ cell and $31 \mathrm{~g} / \mathrm{dl}$ respectively as shown in Table 1. 
Table 1: Haemoglobin and RBC indices in the patients

\begin{tabular}{|c|c|c|}
\hline Hb (g/dl) & n (\%) & Mean \\
\hline $3-5 \mathrm{~g} / \mathrm{dl}$ & $3(8.6)$ & \multirow{4}{*}{$6.9 \mathrm{~g} / \mathrm{dl}$} \\
\hline$>5-7 \mathrm{~g} / \mathrm{dl}$ & $15(42.9)$ & \\
\hline$>7-10 \mathrm{~g} / \mathrm{dl}$ & $17(48.5)$ & \\
\hline PCV $(\%)$ & $\mathrm{n}(\%)$ & \\
\hline$<20$ & $10(28.6)$ & \multirow{4}{*}{$22 \%$} \\
\hline $20-30$ & $24(68.6)$ & \\
\hline$>30$ & $1(2.8)$ & \\
\hline MCV (fl) & n (\%) & \\
\hline$<80$ & $13(37.1)$ & \multirow{4}{*}{$83 \mathrm{fl}$} \\
\hline $80-85$ & 8 (22.9) & \\
\hline$>85$ & $14(40)$ & \\
\hline MCH (pg/cell) & n (\%) & \\
\hline$<30$ & $12(34.3)$ & \multirow{4}{*}{$25.8 \mathrm{pg} / \mathrm{cell}$} \\
\hline $30-32$ & $7(20)$ & \\
\hline$>32$ & $16(45.7)$ & \\
\hline MCHC (g/dl) & $\mathrm{n}(\%)$ & \\
\hline$<28$ & $21(60)$ & \multirow[b]{2}{*}{$31 \mathrm{~g} / \mathrm{dl}$} \\
\hline $28-33$ & $14(40)$ & \\
\hline
\end{tabular}

Microcytic hypochromic anaemia was seen in $45.7 \%$ patients. Platelet count of the patients ranged from $0.95 \mathrm{lakh} / \mathrm{mm}^{3}$ to $4.27 \mathrm{lakhs} / \mathrm{mm}^{3}$ with a mean of 2.8 lakhs $/ \mathrm{mm}^{3}$. Only 2 cases had a platelet count less than $1.3 \mathrm{lakh} / \mathrm{mm}^{3}$. None of the patients had significant thrombocytosis. 68\% patients had an erythrocyte sedimentation rate (ESR) greater than $70 \mathrm{~mm} / 1^{\text {st }}$ hour.13 patients had an ESR more than $100 \mathrm{~mm} / 1^{\text {st }}$ hour. The lowest ESR was $20 \mathrm{~mm} / 1^{\text {st }}$ hour.

Red cell distribution width (RDW) was more than $15 \%$ in $54 \%$ patients. The highest RDW was $17.8 \%$ and the mean RDW was $15.1 \%$. Reticulocyte count was between 2 to $4 \%$ in $26 \%$ patients and less than $2 \%$ in rest of the patients. The Reticulocyte production index (RPI) was less than 1 in all the patients, the highest value being 0.74 . Mean reticulocyte count was 2 .

The values of serum Creatinine ranged between 3.1 to $18 \mathrm{mg} / \mathrm{dl}$. The mean creatinine was $9.79 \pm$ $6: 94 \mathrm{mg} / \mathrm{dl}$. Blood urea level varied from 78 to 243 $\mathrm{mg} / \mathrm{dl}$ and mean level was 163.1. The Glomerular Filtration rate ranged from $3.3 \mathrm{ml} / \mathrm{min}$ to $17.4 \mathrm{ml} / \mathrm{min}$. and the mean GFR was $8.13 \mathrm{~mL} / \mathrm{min}$ \pm 3.09 . Calcium level ranged between $6.5 \mathrm{mg} / \mathrm{dl}$ to $10.5 \mathrm{mg} / \mathrm{dl}$. The mean level was $8.8 \mathrm{mg} / \mathrm{dl}$. In 20 patients, it was less than $9 \mathrm{mg} / \mathrm{dl}$. Significant correlation was seen between calcium level and creatinine but not between calcium level and hemoglobin level $(\mathrm{p}=0.14)$. Mean uric acid was $5.25 \mathrm{mg} / \mathrm{dl} .3$ patients had an elevated serum uric acid. Albumin levels ranged from a minimum of $1.2 \mathrm{~g} / \mathrm{dl}$ to $4.3 \mathrm{~g} / \mathrm{dl}$ and average level was $2.7 \mathrm{~g} / \mathrm{dl}$. 20 patients had albumin levels less than $3 \mathrm{~g} / \mathrm{dl}$. Only 3 patients had albumin more than or equal to $3.5 \mathrm{~g} / \mathrm{dl}$. Significant correlation was seen between serum Albumin levels and severity of anemia.

Serum Ferritin ranged from 20 microgram/L to 800 micro gram $/ \mathrm{L}$. Ferritin level $<100$ micro gram/L was seen in 14 cases, of whom, 5 had levels less than 50 micro gram $/ \mathrm{L}$. Those with levels of ferritin less than $50 \mathrm{pg} / \mathrm{L}$ had absent bone marrow iron stores. Bone Marrow Cellularity was normal in $62.9 \%$ patients. 10 cases had grades more than $3+$ as shown in figure 3 . Bivariate analysis using Kendall Correlation Coefficient revealed a positive correlation coefficient of 0.731 with a $p$ value of 0.01 between serum ferritin and bone marrow iron.

Figure 3: Frequency Distribution of Grades of Marrow Iron

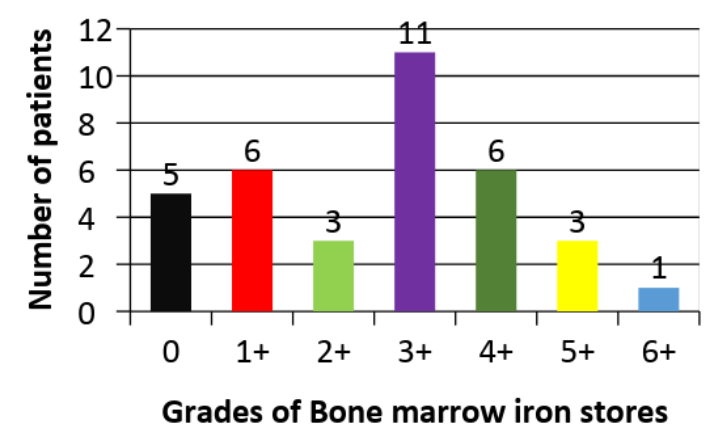

$40 \%$ of cases (14 cases) had ferritin level less than $100 \mathrm{pg} / \mathrm{L}$. Of these cases, $78.5 \%$ (11 cases) had hypochromic microcytic anemia. Marrow iron was absent in only $31 \%$ of these patients. All the 5 patients with absent bone marrow iron had hypochromic microcytic anemia. Among patients with hypochromic microcytic anemia, 68\% had ferritin levels less than $100 \mathrm{pg} / \mathrm{L}$. The highest ferritin level among those with hypochromic microcytic anemia was $408 \mathrm{pg} / \mathrm{L}$. This patient also had a high level of iron stores in the bone marrow. 5 patients had iron stores more than $2+$ and ferritin more than $100 \mathrm{pg} / \mathrm{L}$ with the blood picture showing hypochromic microcytic anemia. 


\section{Discussion}

$60 \%$ of the study population were males. The mean age was 57 years. The most common cause of chronic Kidney Disease was Diabetes Mellitus, followed by Hypertension. This correlates well with other western and Indian studies ${ }^{7,15}$

Mean $\mathrm{Hb}$ level in the present study was $6.9 \mathrm{gm} / \mathrm{dl}$. There was a significant correlation between the severity of anemia and severity of renal failure as was seen in several studies ${ }^{3,5}$. In our study, mean MCV was 83 and $60 \%$ had low MCV, mean MCHC was 31 and mean $\mathrm{MCH}$ was 25.8. Red cell indices were consistent with the findings in a study by Talwar et $\mathrm{al}^{15}$ where mean MCV was 83 with $61 \%$ having a low MCV, mean MCHC was 32.3 and mean $\mathrm{MCH}$ was 27.14 with $61 \%$ having low values of $\mathrm{MCH}$. In the present study, $54 \%$ had RDW more than $15 \%$. Docci et al reported that RDW tends to be higher in those with uremia compared to healthy individuals ${ }^{8}$ A study by Talwar et $\mathrm{al}^{15}$ reported a mean RDW of 15.35 with $67 \%$ of patients with RDW more than $14 \%$.

Talwar et al also reported a mean reticulocyte count of $1.92 \%$ with $45 \%$ cases having high reticulocyte count. In the present study mean reticulocyte count was $2 \%$. Only $26 \%$ had high reticulocyte count, but in all cases the reticulocyte production index was less than 1 , which is expected; given the fact that there is a defect in erythrocyte production and maturation in any patient with anemia of chronic renal failure. In the present study $45.7 \%$ cases had hypochromic microcytic anemia. This is in variance from a study by Callen et $\mathrm{al}^{5}$ who found that $81 \%$ of patients with chronic renal failure had normocytic normochromic anemia, $4 \%$ had microcytic hypochromic anemia and $15 \%$ had macrocytic anemia $^{3}$. Talwar et al ${ }^{15}$ reported $60 \%$ Arun et al reported combined microcytic anemia and normochromic anemia $^{2}$ the prevalence of hypochromic microcytic anemia in the present study was higher than the data from western studies and lower than other Indian studies. Variance from this study can be explained by better diet, lower rates of chronic illness such as tuberculosis and possibly due to lower parasitic infection rate. Moreover in the study by Talwar et $\mathrm{al}^{15}$, there was a significant number of cases with absolute eosinophilia which the authors had attributed to the high rate of parasitic infection. This observation was not seen in the present study.

Mean creatinine value in the present study was 9.8 $\mathrm{mg} / \mathrm{dl}$ and mean blood urea was 163 . In the study by Talwar et $\mathrm{al}^{15}$ done on 28 patients with CRF (with /without anemia, the mean creatinine was $7.3 \mathrm{mg} / \mathrm{dl}$ and mean blood urea was $107 \mathrm{mg} / \mathrm{dl}$ respectively. ESR was elevated in majority of cases. 54\% of cases had ESR more than 100 $\mathrm{mm} / 1^{\text {st }}$ hour, most of whom were diabetic.

Bone marrow examination showed Normocellular marrow in the majority of cases similar to studies done elsewhere ${ }^{5,15}$. Bone marrow iron stores were absent in 5 cases in the present study and it was increased (grade 5+ and 6+) in 4 patients. Blumberg A.B. et al studied 20 patients on Continuous Ambulatory peritoneal Dialysis and found absent marrow iron in 8 cases $^{4}$. Prevalence of iron deficiency was $50 \%$ in the study conducted by Gupta et al on marrow iron estimation based on the combined use of serum ferritin and serum transferrin receptor. ${ }^{11}$ Thalib S.H et al studied 190 CKD patients and reported an incidence of $42.63 \%{ }^{16}$. There is a lack of correlation with other Indian studies which could be attributed to the dietary characteristics and better health awareness of the patient population of Kerala. Analysis of the present series show significant correlation between serum ferritin level and bone marrow iron status, with a $\mathrm{p}$ value $<0.05$. Many groups have shown that serum ferritin concentration correlate well with iron stores. ${ }^{15,4}$ 12,3

Considering $100 \mathrm{ug} / \mathrm{L}$ as the threshold of normal range of serum ferritin in patients with $\mathrm{CKD}$, then the sensitivity of the test in detecting an absence of iron store is $100 \%$ and the specificity is $70 \%$. The negative predictive value of a ferritin level of $>100 \mathrm{ug} / \mathrm{L}$ is $100 \%$. According to this study the chance that a patient with ferritin $>100 \mathrm{ug} / \mathrm{L}$ has absent bone marrow iron is nil. Thus ferritin 
estimation can be considered as a good screening test in CKD patients being evaluated for possible iron deficiency. Mirahmadi KS et al reported that Ferritin level less than $105 \mathrm{ug} / \mathrm{L}$ suggest decreased iron stores ${ }^{13 .}$ Milman $\mathrm{N}$ et $\mathrm{al}^{12}$ in his study in 50 non dialysis patients and 50 controls, Serum Ferritin less than $60 \mathrm{ug} / \mathrm{L}$ was associated with absent or reduced marrow iron and concentrations greater than $80 \mathrm{microgram} / \mathrm{L}$ was associated with normal marrow iron. Fernandez-Rodriguez et al in his series of 63 patients on dialysis reported serum ferritin cut off point at 121 microgram $/ \mathrm{L}^{9}$. All these 3 series correlate well with the present study with regard to the utility of Serum ferritin in the diagnosis of deficient iron stores in patients with anemia of chronic renal failure. In the present series, $45.7 \%$ cases had hypochromic anemia and $31.6 \%$ of them had absent marrow iron. 5 cases had normal ferritin ranging from 124 to 408. A significant proportion of patients with hypochromic anemia had good iron stores. This can be attributed to functional iron deficiency ${ }^{6}$. $11.5 \%$ of cases had increased bone marrow iron, one patient had bone marrow iron grading of $6+$ and serum ferritin of 800 . Hussein et al reported a high prevalence of iron overload but further trials have not substantiated the finding ${ }^{10}$. The corresponding prevalence reported by Milman et $\mathrm{al}^{12}$ was $6.6 \%$ and that by Talwar et $\mathrm{al}^{15}$ was $18.5 \%$. Thus the present study highlights the possibility of iron overload in the setting of anemia of CKD. Simon P et al reported body iron overload in patients receiving blood transfusion and iron while on maintenance dialysis ${ }^{14}$.

\section{Conclusion}

Serum ferritin estimation is a good screening test in estimating the iron status of patients with anemia of Chronic Kidney Disease. It was seen to have a significant correlation with bone marrow iron stores. A serum ferritin of less than $100 \mathrm{ug} / \mathrm{L}$ has a sensitivity of $100 \%$ and a specificity of $70 \%$ in detecting absence of marrow iron. The prevalence of hypochromic microcytic anemia was $45.7 \%$ and normochromic normocytic anemia was $54.3 \%$.A significant number of cases with hypochromic microcytic anemia bone marrow iron had normal marrow iron.

\section{Conflict of Interest: Nil}

\section{References}

1. Agarwal S.K. Prevalence of chronic renal failure in India. Proceedings of $34^{\text {th }}$ Annual conference of Indian society of Nephrology, Visakhapatnam A.P, December 2003.

2. Arun $\mathrm{S}$ M, Venkatraya Prabhu, K Nithyananda chowtha, Mridhula Laxman Bengre.The haematological pattern of patients with chronic kidney Disease in a tertiary care set up in south India JCDR 2012 Aug 6:1003-1006.

3. Bell JD, Kincaid WR, Morgan RG Buncett Alperin JB, Sarles HE, Remmers AR Jr. Serum ferritin assay and bone marrow iron stores in patients on maintenance hemodialysis. Kidney International 1980 Feb; 17(2):237-41.

4. Blumberg AB, Marti HR, Graber CG. Serum Ferritin and bone marrow iron in patients undergoing continuous ambulatory peritoneal dialysis. JAMA 1983 Dec 23-30; 250(24):3317-9.

5. Callen IR, Lamaze. Blood and marrow studies in renal diseases. Am J Clin Path 1950; 20):3-25.

6. Clara Camaschella. Iron deficiency anemia.NEJM 2015 May;372:1832-1843

7. David B mount, Joseph Localzo Chronic Renal Failure.in: Kasper DL, Fauci AS, Hauser SL, Longo DL, Jameson J L, Localzo $\mathrm{J}$ eds.Harrisons manual of medicine. $19^{\text {th }}$ ed.Newyork: McGraw Hill Education; 2016 Vol.1, 771-2.

8. Docci D, Delveechio C, Gollini C, Turci F, Buldrati L, Gilli P. Red cell distribution width in uremic patients on chronic hemodialysis. Int J Artif Organs 1989 March 12(3):170-4. 
9. Fernandez-Rodriquez AM et al. Diagnosis of iron deficiency in chronic renal failure. American journal of Kidney diseases. 1999 Sep; 34(3):508-13.

10. Hussein, J Prieto, M O'shea, A V Hoffbrand, RA Aillod, JF Moorhead. Serum ferritin assay and iron status in chronic renal failure and hemodialysis. British Medical Journal, 1975; (1):546-48.

11. Meenal Gupta, Kannan M, Sanjay Gupta, Renu Saxena. Contribution of iron deficiency anemia in chronic renal failure. Indian J of Pathol Microbiol 2003 Oct; 46(4):563-564.

12. Milman N, Bangsholl S, Peder Sen NS, Visfeld J. Serum ferritin in non-dialysis patients with chronic renal failure: relation to bone marrow iron stores. Scand $\mathrm{J}$ Haematol 1983 Apr; 30(4): 337-44.

13. Mirahmadi KS et al. Serum ferritin level, Determinant of iron requirement in hemodialysis patients. J Am a 1977 Aug15; 238(7):601-3.

14. Simon P, Bonn F, Guezennec M, Tanquerel T, K Sanoj. Iron overload in patients on maintenance dialysis, Diagnostic criteria, indications and treatment by Desferrioxamine. Nephrology 1981; 2(4):165-70.

15. Talwar V K, Gupta H L, Shahinarayan. Clinico hematological profile of chronic renal failure. JAP, Feb 2002 ;(50):228233.

16. Thalib SH, Kulkarni SG, Gulwe VS. Vajed Mogal Role of Iron Deficiency Anemia in patients with Chronic Kidney Disease. JOSR-JDMS 2015; may14 (5): 102-105. 